\title{
IMPLEMENTATION OF CO-CREATION BY USING STUDENTS' MASTERY OF10 SKILLS AS A NEW PRODUCT IN HIGHER EDUCATION 4.0
}

\author{
Kastolani $^{1^{*}}$, Rr. Wuri Arenggoasih ${ }^{2}$, Sika Nur Indah $^{3}$, Muslimah Susilayati $^{4}$ \\ ${ }^{1 * 2}$ Faculty of Dakwah and Communication, Institut Agama Islam Negeri Salatiga, Indonesia; ${ }^{3}$ Faculty of Social and \\ Political Science, Universitas Pembangunan Nasional Veteran Yogyakarta, Indonesia; ${ }^{4}$ Faculty of Teacher Training and \\ Education, Institut Agama Islam Negeri Salatiga, Indonesia. \\ Email: ${ }^{1 *}$ kastolani@iainsalatiga.ac.id, ${ }^{2}$ rorowuri@iainsalatiga.ac.id, ${ }^{3}$ sikanurin@upnyk.ac.id, \\ ${ }^{4}$ muslimahsm@iainsalatiga.ac.id
}

Article History: Received on $8^{\text {th }}$ January 2020, Revised on $26^{\text {th }}$ May 2020, Published on $13^{\text {th }}$ July 2020

\begin{abstract}
Purpose of the study: To determine the effectiveness of co-creation implementation by using students' mastery of 10 skills as a new product, and to analyze the readiness stage for digitally integrated marketing communication 4.0 in higher education.

Methodology: The technique of data collection was administered by giving questionnaires to respondents. The questionnaire consisting of 10 closed questions was created by researchers. Afterward, the data were processed by the SPSS application. The results proved to be valid if each indicator question had a value of Pearson correlation significant 1 -tail less than 0.05 . Meanwhile, the data are reliable if the Cronbach's alpha reliability value is more than 0.60 . The average final score can be converted into a level of product quality qualitatively with ideal assessment guidelines.

Main Findings: The average percentage of students' mastery of 10 skills in IAIN Salatiga is 47 percent for ability to solve complex problems, 49 percent for critical thinking, 50 percent for creativity, 51 percent for organizational ability, 57 percent for ability to corporate, 52 percent for emotional intelligence, 55 percent for daring to make a decision, 54 percent for contentment to serve, 52 percent for negotiation ability, and 55 percent for flexibility thinking. The students 'mastery average of all skills is 52 percent in the range of Fair $(F)$. The readiness to continue the next steps of digital integrated marketing 4.0 is quite ready $(\mathrm{QR})$.
\end{abstract}

Applications of this study: This study can be useful for practical review for the implementation of co-creation in higher education as the new vision of marketing in the 4.0 era.

Novelty/Originality of this study: This study proposes that the effectiveness of co-creation in higher education can be measured by the students' mastery of the 10 skills.

Keywords: Co-creation, Costumers, Higher Education, New Product, Students' Mastery.

\section{INTRODUCTION}

The digital revolution that has become a marker of the era of industry 4.0 has changed the entire order. Rapid (disruptive) changes lurk all sectors, including higher education. An article discussing whether the UK has prepared its students to face the 4.0 era states that this change could not be rejected, as Darwin's theory of evolution says, the best way to survive is to adapt (Mc Lellan, 2018). In line with the disruption of marketing theory and practices in higher education, its success is not only based on product orientation but also based on market orientation. Higher education adapts by supplying new products based on market needs. Marketing in higher education does not merely provide sweet promises related to facilities and work guarantees, without fixing the substance of the services offered (Sihite, 2016). This is further strengthened by the need for the role of Higher Education as the vanguard in the global response of the COVID-19 pandemic within the framework of "The Great Reset" (Dodgson \& Gann, 2020).

Disruption of marketing theory and practices in higher education has influenced the way to achieve its role and function. Higher education can achieve success by adapting its disruption. What is the disruption of marketing theory and practices in higher education? Why higher education needs market orientation? What is the correlation between market orientation and new product? What is a new product in higher education 4.0? Disruption in higher education is inseparable from the communication aspects of marketing starting from the marketing mix, integrated marketing communication, marketing 4.0 to digitally integrated marketing communication 4.0 that are discussed below.

\section{Marketing Mix Concept}

The marketing mix is inseparable from the 4Ps model introduced by E. Jerome McCarthy namely Product, Price, Place, Promotions. The marketing mix is defined as a concept that includes all the tools used by marketers to develop effective actions and penetrate sales targets in a target market. A marketing mix consisting of all sales decisions and actions warrant the success of a product, service, or brand (50minutes.com).

Products include the concept of goods or services introduced in the market to satisfy the desires or needs after consumption. Rules that bind products include size, quality, design, brand, label, packaging, and so on. Price includes 
the concept of the price offered, discounts, payment terms, and payment methods. Place includes the concept of distribution channels, distribution networks, locations, product availability, transportation, and others. While Promotions include advertising, direct sales, public relations, sponsorship, and others.

In its development, many 4Ps models were developed and modified through the addition of marketing elements. Hermawan in his book Hermawan Kartajaya on Marketing Mix sees that the marketing mix is only part of marketing activities, namely marketing tactics that have not led to marketing strategies. Today, the establishment and use of strategies based on behavior, price, and product compatibility have become trends supported by technological advancements to gather information about consumer purchases and to provide compatible product categories (Wei \& Huang, 2019). The application of the 4P element does not merely support the success of marketing. Differentiated elements need to be applied to make products perceived differently by prospective customers. For products to be perceived differently, it is necessary to build the positioning. The point is that good positioning must be supported by differentiation. While differentiation will not produce results as expected if not communicated effectively (Kartajaya, 2007).

\section{Integrated Marketing Communications}

Marketing communications according to Burnet and Moriarty are elements of the marketing mix that is used to communicate various other important elements in marketing to increase the possibility of purchasing (Estawara, 2008). This definition leads to technical marketing communications. Integration is needed to make it mean more broadly. Integration here cannot only be interpreted as text but also context, which refers to the fact that the rapid development of information technology, changes in the business competition environment, and consumer behavior must be managed appropriately by the company (Estawara, 2008).

The idea of Integrated Marketing Communications (IMC) first emerged from the American Association of Advertising Agency (4As) in 1989 and continues to grow. But Schultz and Schultz's thinking in 1998 was considered the most modern and became the basis for the development of the next IMC. Don Schultz had placed IMC as a strategic process in a customer-oriented business. A series of brand communication programs must be coordinated, measurable, and persuasive at certain periods for targeted and relevant consumers (customers or prospects) that are external or internal hearings. This series is a strategic business process that consists of planning, developing, executing, and evaluating (Schultz, 2003). IMC consists of six elements or categories namely advertising, sales promotions, brand visibility, public relations, digital platforms, and personal contact (Juska, 2017). Each category has a purpose and function in marketing products and services. These elements are combined effectively and efficiently to deliver brand messages.

\section{Marketing 4.0}

The marketing world runs so dynamically. Kotler in his book, Marketing 4.0, describes changes in marketing orientation from the industrial era 1.0 to 4.0. According to him, there is a shift in marketing, product-oriented 1.0 into customeroriented 2.0 marketing. Furthermore, in the marketing era 3.0, the orientation is no longer in the customer but in humans, including the heart, mind, and soul. While in the digital age or marketing 4.0, it is oriented to humans as a brand attraction (Kotler, 2019). The effects of market performance on new wave innovations, targeting, and seeding of new products have been grown and made by managerial marketing decisions as an effect of social network structure (Muller \& Peres, 2019). In the marketing 4.0 era, customers and potential customers utilize the online network to interact with fellow Internet users in finding their favorite products, while communicating with brand communicators. In other words, they create their marketing channel (Tarabasz, 2013).

Marketing 4.0 does not just turn consumers into a propagandist for their company or product. This type of marketing is ideal, democratic, holistic, and altruistic, rather than just focusing on customer interest (Krauss, 2017). Mutual involvement that integrates buyers and sellers in cooperative interactions to account for group identities, individual packaging senses, and marketing potential is an important force in marketing 4.0 that converts customers into an advocate (Gau, 2019).

The marketing 4.0 in this digital economy era combines online and offline interactions between companies and customers, integrating style with substance in brand building, to be further connected between machines to machines and a human-to-human touch so that customer involvement is getting tighter (Kotler, 2019). Schultz (2003) argues that a change is influenced by three things, namely the development of pressure on digital technology that has spread throughout the entire spectrum of business operations, increasing brand pressure as the main differentiating tool in competition, and increasing multinational focus and globalization as a marketing reach.

The concept of the marketing mix known as $4 \mathrm{Ps}$ in the 4.0 era has also transformed $4 \mathrm{C}$, namely Co-creation, Currency, Communal Activation, and Conversation. Co-creation is a new product development strategy involving customers. Currency is a dynamic pricing strategy that allows one customer with another to get different prices. Communal Activation is a product distribution channel with the peer-to-peer concept namely products and services that can be obtained almost instantly. Finally, Conversation is a promotional concept that allows companies with customers or 
customers with other customers to exchange messages (Kotler, 2019). This 4C concept is the basis for describing the results of research at IAIN Salatiga.

\section{Graduates' Skills as New Product of Co-creation}

Market orientation consists of two aspects of assessment (i.e. orientation on the consumer (customer orientation) and orientation on the competitor (competitor orientation). Customer orientation means that higher education is required to continually innovate to adapt to those needs, namely 10 skills in working. Meanwhile, competitor orientation is a reference for higher education in marketing activities. In this activity, higher education is also required to understand and translate who is a competitor and how to deal with it. In other words, higher education can position their graduates in the workforce. Research conducted by Robles (2012) identifies 10 skills that are considered important for business executives. Interpersonal skills such as being honest, able to communicate well, to work together, and to work hard are considered in accepting workers. This study has not specifically examined how universities prepare workers for these skills.

On the other hand, mastery of work skills in the 4.0 era must be the subject of university thinking. Former DirectorGeneral of Higher Education, Satryo Soemantri stated that one of the indicators of the success of higher education in terms of students is the output expectations and outcomes of students who have hard skills, soft skills, and life skills (Puspitarini, 2014). According to Ginting (2014), the idea to innovate (make new products) should not be vertical but horizontal through open innovation by putting the customer brand community at the center of innovation. Based on market orientation, human resources are always required to have awareness and the ability to face changes and keep going. The Future of Jobs has discussed employment strategies, workforce skills for the future. Industry 4.0 will bring sophisticated robotics and autonomous transportation, artificial intelligence, and machine learning, advanced materials, biotechnology, and genomics (Gray, 2016). This change will certainly require changes in the skills of workers. The World Economic Forum presents 10 skills needed by the workforce in the era of the industrial revolution, namely: Complex Problem Solving, Critical Thinking, Creativity, People Management, Coordinating with Others, Emotional Intelligence, Judgment and Decision Making, Service Orientation, Negotiation, and Cognitive Flexibility (Gray, 2016). Research that has been conducted at several private tertiary institutions in South Sumatra Province, Indonesia, shows that the co-creation model has an impact on good marketing strategies. Its short-term impact is on the value of institutional experience and image. Its medium-term impact is on user satisfaction and trust. Its long-term impact is on students' loyalty (Gunarto, 2018).

Certainly, in determining the direction of this expectation, it would be wiser if higher education adjusts to marketoriented in the era of industrial revolution 4.0 which requires students to have 10 skills. This is an important part of cocreation. The involvement of analytical and interpretative skills in planning and making important decisions must be trained and then must obtain better results in the marketing with strategy and leadership (D'Alessio et al., 2019).

Hendra Tanumihardja, Executive Vice President of the Human Capital Management Division at BCA Bank revealed that when building capability in the skills of the 4.0 era, three elements need to be considered by higher education, namely employee mindset, employee competencies, and employee governance (Hendriyana, 2019). Hendra explained the first element is about what mindset needed following the type of organization to be built and the second one is about what competencies need to be built to be able to have competitiveness while the third one is about what kind of management needs to be built so that the organization can be run effectively (Hendriyana, 2019). The results of a survey of 10 skill items on digital information and communication skills, collaboration, critical thinking, plus creative digital skills show gradients of difficulty and have a sequential and conditional nature. It means, these skills build on each other sequentially and will not be enough if they improve a specific skill alone (Laar, Deursen, Dijk, \&Haan, 2019). The development of Industry 4.0 in the world has increased the connectivity, interaction, and convergence between people, machines, and other resources through information communication technology. The reason is that the media can bring up social action and joint acts which is a solution to overcome problems, especially in the workplace. Thus, 10 skills are needed (Arenggoasih, 2019). So, higher education must give graduates market orientation in the workforce with 10 skills as a new product at work. This is an important part of co-creation.

Therefore, research on marketing in higher education as an effort to provide a new market-oriented product is important to do. If the university has the right design to provide the new product, it will likely be able to exist and win the competition. In marketing theory, the new product can be obtained through co-creation. So, we consider these following objectives to be selected for the study.

1. To determine the effectiveness of co-creation that has been conducted at IAIN Salatiga by using students' mastery of 10 skills as a new product,

2. To analyze the readiness to continue the next stage for digital integrated marketing communication 4.0 in higher education. 


\section{METHODOLOGY}

This research is a quantitative descriptive research study which aims to find out the implementation of co-creation by using students' mastery of 10 skills as a new product and to analyze the readiness stage of digital integrated marketing 4.0 in higher education through a systematic description of facts and actual characteristics of a particular population or object (Kriyantono, 2014). The study was conducted at Institut Agama Islam Negeri (IAIN) Salatiga, Indonesia.

The research population is all students of IAIN Salatiga, totaling 12.796 students. The sample obtained is 388 students as respondents determined based on the Slovin's formula with a 5 percent error margin. To represent all participants, the sampling technique used was stratified random sampling because the population came from different faculties and provided them the same opportunities. So, the sample needed arrangements in strata, and after that, the proportions were performed randomly as usual. They came from the Faculty of Islamic Communication, the Faculty of Economics and Islamic Business, the Faculty of Islamic Law, the Faculty of Teacher Training and Education, and the Faculty of Islamic Religion. Then, stratification and proportional retrieval are obtained as presented in Table 1.

Table 1: Stratification and proportional retrieval of the sampling

\begin{tabular}{ccccc}
\hline No. & Faculty & $\begin{array}{c}\text { Number of } \\
\text { students }\end{array}$ & Percentage (\%) & Sample \\
\hline 1. & Islamic Communication & 1.325 & 10 & 40 \\
\hline 2. & Islamic Economics and Business & 3.048 & 24 & 92 \\
\hline 3. & Islamic Law & 1.609 & 13 & 49 \\
\hline 4. & Teacher Training and Education & 5.907 & 46 & 179 \\
\hline 5. & Islamic Religion & 907 & 7 & 388 \\
\hline & Total & 12.796 & 100 & \\
\hline
\end{tabular}

Source: Researchers' document counted from IAIN Salatiga academic data 2018/2019

The technique of data collection was administered by giving questionnaires to respondents. The questionnaire consisting of 10 closed questions was created by researchers. Then, the questionnaire was filled in by respondents with a score interval of 0-100 percent for 10 work skills. After that, the answers to the questionnaire were processed by the SPSS application. The results proved to be valid if each indicator question had a value of Pearson correlation significant 1-tail less than 0.05 . The reliability test used Cronbach's alpha value of more than 0.60 . The average final score can be converted into a level of product quality qualitatively with ideal assessment guidelines modified from Widoyoko, 2009 in Table 3. Data were analyzed descriptively with the concept of integrated marketing communication and education theory so that the recommendations for the implementation of co-creation and readiness of digitally integrated marketing communication 4.0 for higher education were generated.

Table 2: Ideal criteria of assessment

\begin{tabular}{llll}
\hline No & Score Range & Quality Category & $\begin{array}{l}\text { Readiness to continue the next } \\
\text { steps of digitally integrated } \\
\text { marketing communication 4.0 }\end{array}$ \\
\hline 1. & $\bar{X}>M_{i}+1,8 S B_{i}$ & Very Good (VG) & Very ready (VR) \\
\hline 2. & $M_{i}+0,6 S B_{i}<\bar{X} \leq M_{i}+1,8 S B_{i}$ & Good (G) & Ready (R) \\
\hline 3. & $M_{i}-0,6 S B_{i}<\bar{X} \leq M_{i}+0,6 S B_{i}$ & Fair (F) & Quite ready (QR) \\
\hline 4. & $M_{i}-1,8 S B_{i}<\bar{X} \leq M_{i}-0,6 S B_{i}$ & Poor (P) & Less ready (LR) \\
\hline 5. & $\bar{X} \leq M_{i}-1,8 S B_{i}$ & Very Poor (VP) & Very less ready (VLR) \\
\hline
\end{tabular}

Source: Authors' document modified form Widoyoko, 2009

Information:

Mi = Ideal average, which is searched by the formula:

$M_{i} \quad=(1 / 2)$ x (the ideal highest score + the ideal lowest score)

$\mathrm{SBi}=$ Ideal standard deviation, which is sought by the formula:

$M_{i} \quad=(1 / 2) \times(1 / 3) \times$ (the ideal highest score-the ideal lowest score)

The ideal highest score $=\Sigma$ item rating $\mathrm{x}$ highest score

\section{RESULTS/FINDINGS}

The reliability test shows that all data are reliable by the Cronbach's alpha value at 0.9840 .01 . Detailed results of the reliability test are presented in Table 3 below. 
Table 3: The results of the reliability test

\begin{tabular}{|c|c|c|c|c|}
\hline \multicolumn{5}{|c|}{ Item-Total Statistics } \\
\hline & $\begin{array}{c}\text { Scale Mean } \\
\text { if Item } \\
\text { Deleted }\end{array}$ & $\begin{array}{c}\text { Scale } \\
\text { Variance if } \\
\text { Item Deleted }\end{array}$ & $\begin{array}{l}\text { Corrected } \\
\text { Item-Total } \\
\text { Correlation }\end{array}$ & $\begin{array}{c}\text { Cronbach's } \\
\text { Alpha if Item } \\
\text { Deleted }\end{array}$ \\
\hline VAR01 & 473.26 & 55581.656 & .915 & .983 \\
\hline VAR02 & 470.93 & 55173.814 & .912 & .983 \\
\hline VAR03 & 470.53 & 55086.606 & .912 & .983 \\
\hline VAR04 & 468.98 & 54616.855 & .899 & .983 \\
\hline VAR05 & 463.36 & 54402.160 & .940 & .982 \\
\hline VAR06 & 468.80 & 54531.958 & .936 & .982 \\
\hline VAR07 & 464.96 & 54358.073 & .940 & .982 \\
\hline \multirow[t]{2}{*}{ VAR08 } & 465.99 & 54848.561 & .898 & .983 \\
\hline & $\begin{array}{c}\text { Scale Mean } \\
\text { if Item } \\
\text { Deleted }\end{array}$ & $\begin{array}{c}\text { Scale } \\
\text { Variance if } \\
\text { Item Deleted }\end{array}$ & $\begin{array}{c}\text { Corrected } \\
\text { Item-Total } \\
\text { Correlation }\end{array}$ & $\begin{array}{c}\text { Cronbach's } \\
\text { Alpha if Item } \\
\text { Deleted }\end{array}$ \\
\hline VAR09 & 468.03 & 55008.570 & .924 & .983 \\
\hline VAR10 & 464.81 & 54204.032 & .935 & .982 \\
\hline \multicolumn{5}{|c|}{ Case Processing Summary } \\
\hline & & $\mathrm{N}$ & & $\%$ \\
\hline \multirow[t]{3}{*}{ Cases } & Valid & 388 & \multicolumn{2}{|c|}{100.0} \\
\hline & Excluded $^{\mathrm{a}}$ & 0 & \multicolumn{2}{|c|}{0.0} \\
\hline & Total & 388 & \multicolumn{2}{|c|}{100.0} \\
\hline \multicolumn{5}{|c|}{ Reliability Statistics } \\
\hline \multicolumn{2}{|c|}{ Cronbach's Alpha } & \multicolumn{2}{|c|}{$\mathrm{N}$ of Items } & \\
\hline \multicolumn{2}{|c|}{.984} & \multicolumn{2}{|c|}{10} & \\
\hline
\end{tabular}

Source: Researchers document was counted from research data

The validity test shows that all data are valid by the Pearson correlation value 1-tail at 0.01 . Detailed results of the validity test are presented in Table 4 below.

Table 4: The results of the validity test

\begin{tabular}{|c|c|c|c|c|c|c|c|c|c|c|c|c|}
\hline & & $\begin{array}{c}\text { VAR } \\
01 \\
\end{array}$ & $\begin{array}{c}\text { VAR0 } \\
2 \\
\end{array}$ & $\begin{array}{c}\text { VAR } \\
\text { 03 } \\
\end{array}$ & $\begin{array}{c}\text { VAR } \\
04 \\
\end{array}$ & $\begin{array}{c}\text { VAR0 } \\
5 \\
\end{array}$ & $\begin{array}{c}\text { VAR0 } \\
6 \\
\end{array}$ & $\begin{array}{c}\text { VAR0 } \\
7 \\
\end{array}$ & $\begin{array}{c}\text { VAR0 } \\
8 \\
\end{array}$ & $\begin{array}{c}\text { VAR0 } \\
9 \\
\end{array}$ & $\begin{array}{c}\text { VAR } \\
10 \\
\end{array}$ & $\begin{array}{l}\text { tot } \\
\text { al }\end{array}$ \\
\hline \multirow[t]{3}{*}{$\begin{array}{c}\text { VAR } \\
01\end{array}$} & $\begin{array}{c}\text { Pearson } \\
\text { Correlat } \\
\text { ion } \\
\end{array}$ & 1 & $.907^{* *}$ & $.882^{* *}$ & $.831^{*}$ & $.862^{* *}$ & $.883^{* *}$ & $.863^{* *}$ & $.798^{* *}$ & $.839^{* *}$ & $.860^{* *}$ & $.930^{* *}$ \\
\hline & $\begin{array}{l}\text { Sig. (1- } \\
\text { tailed) }\end{array}$ & & .000 & .000 & .000 & .000 & .000 & .000 & .000 & .000 & .000 & .000 \\
\hline & $\mathrm{N}$ & 388 & 388 & 388 & 388 & 388 & 388 & 388 & 388 & 388 & 388 & 388 \\
\hline \multirow{3}{*}{$\begin{array}{c}\text { VAR } \\
02\end{array}$} & $\begin{array}{c}\text { Pearson } \\
\text { Correlat } \\
\text { ion }\end{array}$ & $.907^{*}$ & 1 & $.885^{* *}$ & $\begin{array}{c}.842^{*} \\
*\end{array}$ & $.847^{* *}$ & $.866^{* *}$ & $.863^{* *}$ & $.801^{* *}$ & $.843^{* *}$ & $.855^{* *}$ & $.929^{* *}$ \\
\hline & $\begin{array}{l}\text { Sig. (1- } \\
\text { tailed) }\end{array}$ & .000 & & .000 & .000 & .000 & .000 & .000 & .000 & .000 & .000 & .000 \\
\hline & $\mathrm{N}$ & 388 & 388 & 388 & 388 & 388 & 388 & 388 & 388 & 388 & 388 & 388 \\
\hline \multirow[t]{3}{*}{$\begin{array}{c}\text { VAR } \\
03\end{array}$} & $\begin{array}{c}\text { Pearson } \\
\text { Correlat } \\
\text { ion } \\
\end{array}$ & $.882^{*}$ & $.885^{* *}$ & 1 & $.838^{*}$ & $.867^{* *}$ & $.855^{* *}$ & $.859^{* *}$ & $.825^{* *}$ & $.826^{* *}$ & $.865^{* *}$ & $.929^{* *}$ \\
\hline & $\begin{array}{l}\text { Sig. (1- } \\
\text { tailed) }\end{array}$ & .000 & .000 & & .000 & .000 & .000 & .000 & .000 & .000 & .000 & .000 \\
\hline & $\mathrm{N}$ & 388 & 388 & 388 & 388 & 388 & 388 & 388 & 388 & 388 & 388 & 388 \\
\hline VAR & Pearson & $.831^{*}$ & $.842^{* *}$ & $.838^{* *}$ & 1 & $.898^{* *}$ & $.844^{* *}$ & $.852^{* *}$ & $.816^{* *}$ & $.848^{* *}$ & $.835^{* *}$ & $.919^{* *}$ \\
\hline
\end{tabular}


04 Correlat

\begin{tabular}{|c|c|c|c|c|c|c|c|c|c|c|c|c|}
\hline & $\begin{array}{c}\text { 10n } \\
\text { Sig. (1- } \\
\text { tailed) }\end{array}$ & .000 & .000 & .000 & & .000 & .000 & .000 & .000 & .000 & .000 & .000 \\
\hline & $\mathrm{N}$ & 388 & 388 & 388 & 388 & 388 & 388 & 388 & 388 & 388 & 388 & 388 \\
\hline \multirow[t]{3}{*}{$\begin{array}{c}\text { VAR } \\
05\end{array}$} & $\begin{array}{c}\text { Pearson } \\
\text { Correlat } \\
\text { ion }\end{array}$ & $.862^{*}$ & $.847^{* *}$ & $.867^{* *}$ & $.898^{*}$ & 1 & $.894^{* *}$ & $.890^{* * *}$ & $.874^{* * *}$ & $.891^{* *}$ & $.892^{* *}$ & $.952^{*}$ \\
\hline & $\begin{array}{l}\text { Sig. (1- } \\
\text { tailed) }\end{array}$ & .000 & .000 & .000 & .000 & & .000 & .000 & .000 & .000 & .000 & .000 \\
\hline & $\mathrm{N}$ & 388 & 388 & 388 & 388 & 388 & 388 & 388 & 388 & 388 & 388 & 388 \\
\hline \multirow[t]{3}{*}{$\begin{array}{c}\text { VAR } \\
06\end{array}$} & $\begin{array}{c}\text { Pearson } \\
\text { Correlat } \\
\text { ion } \\
\end{array}$ & $.883^{*}$ & $.866^{* *}$ & $.855^{* *}$ & $.844^{*}$ & $.894^{* * *}$ & 1 & $.904^{* *}$ & $.869^{* * *}$ & $.873^{* *}$ & $.896^{* *}$ & $.949^{* *}$ \\
\hline & $\begin{array}{c}\text { Sig. (1- } \\
\text { tailed) }\end{array}$ & .000 & .000 & .000 & .000 & .000 & & .000 & .000 & .000 & .000 & .000 \\
\hline & $\mathrm{N}$ & 388 & 388 & 388 & 388 & 388 & 388 & 388 & 388 & 388 & 388 & 388 \\
\hline \multirow[t]{3}{*}{$\begin{array}{c}\text { VAR } \\
07\end{array}$} & $\begin{array}{c}\text { Pearson } \\
\text { Correlat } \\
\text { ion } \\
\end{array}$ & $.863^{*}$ & $.863^{* *}$ & $.859^{* *}$ & $.852^{*}$ & $.890^{* * *}$ & $.904^{* * *}$ & 1 & $.883^{* *}$ & $.896^{* *}$ & $.906^{* *}$ & $.952^{* *}$ \\
\hline & $\begin{array}{l}\text { Sig. (1- } \\
\text { tailed) }\end{array}$ & ,000 & ,000 & ,000 & ,000 & ,000 & ,000 & & ,000 & ,000 & ,000 &, 000 \\
\hline & $\mathrm{N}$ & 388 & 388 & 388 & 388 & 388 & 388 & 388 & 388 & 388 & 388 & 388 \\
\hline
\end{tabular}

\begin{tabular}{|c|c|c|c|c|c|c|c|c|c|c|c|c|}
\hline & & $\begin{array}{c}\text { VAR } \\
01\end{array}$ & $\begin{array}{c}\text { VAR0 } \\
2\end{array}$ & $\begin{array}{c}\text { VAR0 } \\
3\end{array}$ & $\begin{array}{c}\text { VAR } \\
04\end{array}$ & $\begin{array}{c}\text { VAR0 } \\
5\end{array}$ & $\begin{array}{c}\text { VAR0 } \\
6\end{array}$ & $\begin{array}{c}\text { VAR0 } \\
7\end{array}$ & $\begin{array}{c}\text { VAR0 } \\
8\end{array}$ & $\begin{array}{c}\text { VAR0 } \\
9\end{array}$ & $\begin{array}{c}\text { VAR1 } \\
0\end{array}$ & $\begin{array}{c}\text { tot } \\
\text { al }\end{array}$ \\
\hline \multirow[t]{3}{*}{$\begin{array}{c}\text { VAR } \\
08\end{array}$} & $\begin{array}{c}\text { Pearson } \\
\text { Correlat } \\
\text { ion } \\
\end{array}$ & $.798^{*}$ & $.801^{* *}$ & $.825^{* *}$ & $.816^{*}$ & $.874^{* *}$ & $.869^{* *}$ & $.883^{* *}$ & 1 & $.865^{* *}$ & $.860^{* *}$ & $.918^{* *}$ \\
\hline & $\begin{array}{l}\text { Sig. (1- } \\
\text { tailed) }\end{array}$ & .000 & .000 & .000 & .000 & .000 & .000 & .000 & & .000 & .000 & .000 \\
\hline & $\mathrm{N}$ & 388 & 388 & 388 & 388 & 388 & 388 & 388 & 388 & 388 & 388 & 388 \\
\hline \multirow[t]{3}{*}{$\begin{array}{c}\text { VAR } \\
09\end{array}$} & $\begin{array}{c}\text { Pearson } \\
\text { Correlat } \\
\text { ion } \\
\end{array}$ & $.839^{*}$ & $.843^{* *}$ & $.826^{* *}$ & $.848^{*}$ & $.891^{* *}$ & $.873^{* *}$ & $.896^{* *}$ & $.865^{* *}$ & 1 & $.908^{* *}$ & $.939^{* * *}$ \\
\hline & $\begin{array}{l}\text { Sig. (1- } \\
\text { tailed) }\end{array}$ & .000 & .000 & .000 & .000 & .000 & .000 & .000 & .000 & & .000 & .000 \\
\hline & $\mathrm{N}$ & 388 & 388 & 388 & 388 & 388 & 388 & 388 & 388 & 388 & 388 & 388 \\
\hline \multirow[t]{3}{*}{$\begin{array}{c}\text { VAR } \\
10\end{array}$} & $\begin{array}{c}\text { Pearson } \\
\text { Correlat } \\
\text { ion } \\
\end{array}$ & $.860^{*}$ & $.855^{* *}$ & $.865^{* *}$ & $.835^{*}$ & $.892^{* * *}$ & $.896^{* *}$ & $.906^{* *}$ & $.860^{* *}$ & $.908^{* *}$ & 1 & $.948^{* *}$ \\
\hline & $\begin{array}{l}\text { Sig. (1- } \\
\text { tailed) }\end{array}$ & .000 & .000 & .000 & .000 & .000 & .000 & .000 & .000 & .000 & & .000 \\
\hline & $\mathrm{N}$ & 388 & 388 & 388 & 388 & 388 & 388 & 388 & 388 & 388 & 388 & 388 \\
\hline \multirow[t]{3}{*}{ total } & $\begin{array}{c}\text { Pearson } \\
\text { Correlat } \\
\text { ion }\end{array}$ & $.930^{*}$ & $.929^{* *}$ & $.929^{* * *}$ & $.919^{*}$ & $.952^{* *}$ & $.949^{* * *}$ & $.952^{* *}$ & $.918^{* *}$ & $.939^{* *}$ & $.948^{* *}$ & 1 \\
\hline & $\begin{array}{l}\text { Sig. (1- } \\
\text { tailed) }\end{array}$ & .000 & .000 & .000 & .000 & .000 & .000 & .000 & .000 & .000 & .000 & \\
\hline & $\mathrm{N}$ & 388 & 388 & 388 & 388 & 388 & 388 & 388 & 388 & 388 & 388 & 388 \\
\hline
\end{tabular}

Source: Researchers' document counted from research data

Note: VAR01 is Ability to Solve Complex Problems; VAR02 is Critical Thinking; VAR03 is Organizational Ability; VAR04 is Ability to Cooperate; VAR05 is Creative; VAR06 is Emotional Intelligence; VAR07 is Dare to Take a Decision; VAR08 is Like to Serve, VAR09 is Negotiation Ability; VAR10 is Flexible Thinking. 
The results of this research show that IAIN Salatiga has been implementing co-creation. The percentage of 10 skill mastery of IAIN Salatiga students is presented in Table 5 below.

Table 5: Average Percentage of mastery of ten students' skills

\begin{tabular}{lll}
\hline No. & 10 Skills & Percentage of Mastery (\%) \\
\hline 1 & Ability to solve complex problems & 47 \\
\hline 2 & Critical thinking & 49 \\
\hline 3 & Creative & 50 \\
\hline 4 & Organizational ability & 51 \\
\hline 5 & Ability to cooperate & 57 \\
\hline 6 & Emotional intelligence & 52 \\
\hline 7 & Dare to take a decision & 55 \\
\hline 8 & Like to serve & 54 \\
\hline 10 & Negotiation ability & 52 \\
\hline & Flexible thinking & 55 \\
\hline
\end{tabular}

Source: Researchers' document counted from research data

Based on the calculation results, it is obtained that $M i$ value is 50 percent and $S B i$ is 15 percent so that the average mastery of 10 students' skills is in the third range with sufficient categories, and quite ready (QR) to continue the next steps of digital integrated marketing and communication as presented in Table 6 below.

Table 6: Qualitative conversion results

\begin{tabular}{|c|c|c|}
\hline Factor & Value & Description of Results \\
\hline $\mathrm{Mi}+1,8 \mathrm{Sbi}$ & 77 & \multirow{4}{*}{$\begin{array}{l}\text { The percentage average is } 52 \% \\
\text { in the range of fair }(\mathrm{F}) \text { and } \\
\text { quite ready (QR) } \\
M_{i}-0,6 S B_{i}<\bar{X} \leq M_{i}+0,6 S B_{i} \\
41<52 \% \leq 59 \%\end{array}$} \\
\hline $\mathrm{Mi}+0,6 \mathrm{Sbi}$ & 59 & \\
\hline $\mathrm{Mi}-0,6 \mathrm{Sbi}$ & 41 & \\
\hline $\mathrm{Mi}-1,8 \mathrm{Sbi}$ & 23 & \\
\hline
\end{tabular}

Source: Researchers' document

\section{DISCUSSION/ANALYSIS}

Disruptions of marketing theory and practices have placed co-creation as the main stage to adapt. There are two aspects of co-creation, co-production, and value-in-use. These two aspects can be observed from students' mastery of 10 skills that needs to thrive in industry 4.0. On the other hand, education theory explains that the gap of students' mastery of skills can be solved with the closed-loop instructional system. Then, other marketing mix aspects that need to be developed for digitally integrated marketing communication run effectively. The co-creation concept in IAIN Salatiga is shown in Figure 1 below.

\section{Co-creation concept in IAIN Salatiga}

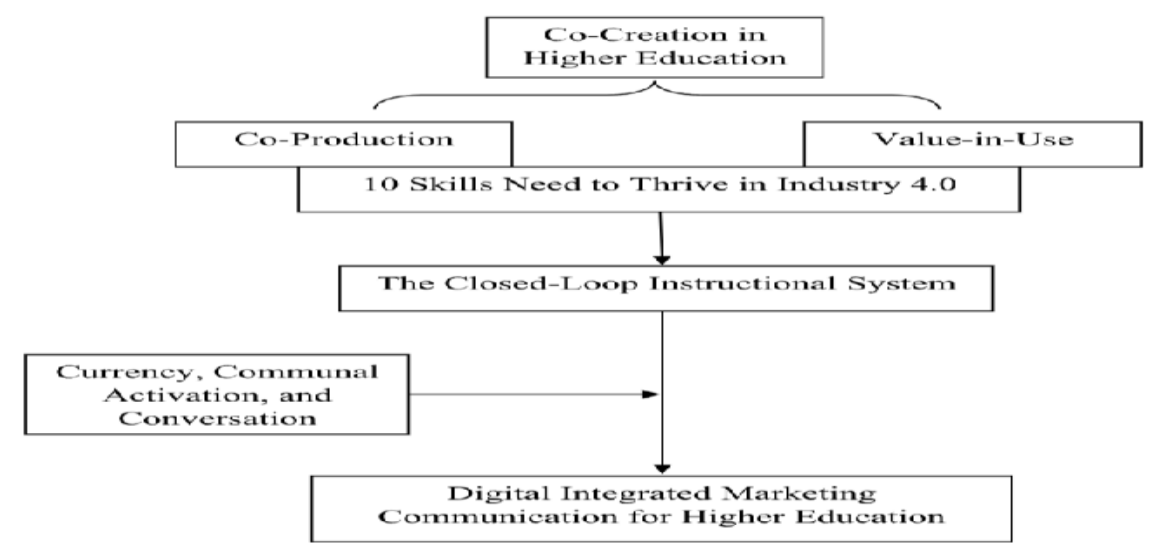

Figure 1: Co-creation concept in IAIN Salatiga

Source: Authors' document 
Figure 1 above shows a new vision of co-creation in higher education. Product-oriented aspects of co-creation in the digital economy also occur in the "business" of higher education. Kotler (2019) reveals that in the digital economy, cocreation is believed to be able to increase the rate of success of new product development through customer involvement in the initial stages of the formation of company ideas. Co-creation also allows customers to customize products and services to create superior values.

In higher education, the process of forming values of co-creation is carried out by institutions and students to increase students' experience and encourage the ability of students' to act as partners (Dollinger, Lodge, \& Coates, 2018). The adoption of the co-creation process forms a reciprocal and balanced relationship with students as "consumers" to sharpen aspects of services, products, and/or delivery (Prahalad \& Ramaswamy, 2004). The two concepts underlying co-creation are co-production and value-in-use (Dollinger, Lodge, \& Coates, 2018).

Co-production involves the integration of student resources, where student knowledge, experience, and opinions influence product creation. Co-production interaction between higher education institutions and students can be seen through the aspects of knowledge, equity, and interaction (Lusch\& Vargo, 2006).

The main foundation of co-production is knowledge, where higher education institutions and students sit together to exchange experiences to create innovations in higher education (Ramirez, 1999). While equity concerns the balance of relationships and equal access between higher education and students to develop and design the value proposition of higher education institutions (Dollinger, Lodge, \& Coates, 2018). Finally, the interaction includes a process that is similar to building an alliance between higher education institutions and students. Students can provide feedback not only at the end but at all times concerning all matters related to the value of higher education institutions (Prahalad \& Ramaswamy, 2004).

If co-production takes place during designing and sending a value proposition, the value-in-use includes what happens to the value after the product or service is used. In the context of higher education, students will not know their educational experience or the quality of their degree until they graduate from college (Dollinger, Lodge, \& Coates, 2018). Three things can inform value-in-use, namely experience, personalization, and relationship (

Experience affects consumers' subsequent behavior of products or services. If students get a positive experience, there will be a positive relationship between products and services, including higher education institutions (Prahalad \& Ramaswamy, 2003). The practice of students then develops into a mechanism of performance that is important for understanding the quality of service (higher-education institutions). The second point of the value-in-use is Personalization, how students can apply higher education experience to their own needs (Dollinger, Lodge, \& Coates, 2018). Furthermore, Relationship complements Experience and Personalization. In higher education, a positive relationship between students and higher education institutions can lead to the establishment of a community in the future that allows predicting collaborative behaviors (Dollinger, Lodge, \& Coates, 2018).

The 10 skills as measured in this study are part of digitally integrated marketing communication conducted by institutions, namely co-creation. In the education sector, students, in addition to being interpreted as consumers, can also be regarded as higher education products that are ready to be absorbed by the industry. Therefore, the success of the institution to provide the labor needed by industry is a value for higher-education institutions.

The collaboration between students and institutions becomes a co-creation aspect to create "products" that can be accepted by the market. The fulfillment of the elements of co-production and value-in-use as part of co-creation can strengthen the value of IAIN Salatiga, which in turn also strengthens the brand and positioning in the community. From the results of the research in Table 5, the study shows that the student's ability to solve complex problems is still fairly enough with 47 percent. This means that the co-production and value-in-use aspects have not been maximized. Institutions have not maximized communication with students to create learning that encourages students to be able to solve various, complex problems. Graduates after graduation will be difficult to adapt to the social condition of society that is full of complex problems. The lack of higher education institutions in preparing graduates with such characters will be a barrier for the institution to have a superior quality of graduates.

The ability of critical thinking with a percentage of 49 percent is still an insufficient category or in other words, has not reached the maximum portion. Critical thinking can be maximized with case-oriented learning. In the scope of the development of a college, an organization should have a good relationship with students as a colleague to participate actively as well as give criticism and advice for the advancement of the institution. Besides, the same opportunities should be given to alumni. Those graduates will get advice as an ingredient to design a learning system that triggers students' critical thinking.

Creative ability points are also in a category with a percentage of 50 percent. Creativity is related to soft skills. Nonmaximized proficiency is possible because the college has not optimally provided a container including funding support to hone the creativity of students, both in-class and outside-class learning. Other possibilities, students who lack interest in the containers are available on campus. However, it requires good communication between students and the campus, hence intertwined synergies to mutual support in improving creativity. Graduates' involvement is also required to boost 
this ability. Graduates can advise and join the campus to talk about the latest soft skills that prospective graduates should have.

Still the same as the previous points, the organizational ability is at the middle level or simply by 51 percent. The proficiency of this one is more obtained outside the lecture, both through internal and external organizations. These nonmaximized capabilities are possible because not all students are interested in organizing, although the campus openly does not restrict organizational activities following the country ideology. Graduates based on their experience in the community can motivate students about the benefits and importance of having organizational skills. The similar results also obtain 52 percent for emotional intelligence, 55 percent for daring to make a decision, 54 percent for contentment to serve, 52 percent for negotiation ability, and 55 percent for flexibility thinking. Students' mastery of these skills needs fixing so that the co-creation runs optimally.

IAIN Salatiga students already have 10 skills needed in the working world in the era of industry 4.0 with an average skill mastery of 52 percent. The lowest results on students' skills in the ability to solve complex problems are equal to 47 percent. Whereas, the highest score on students' skills in the ability to cooperate is 57 percent.

Based on the results of the study, the ability to solve complex problems is the first skill that is even essential in the scope of work in 2020 but ranks lowest among students. Frensch\& Funke (1995) define complex problem-solving as requiring the use of cognitive, emotional, and social and knowledge resources. The reason is that complex problem-solving is an effort to reduce the barrier between the initial state and the desired goal through cognitive and behavioral activities. It is begun with complex problems at the beginning of a problem that must be harmonized with the features of the right solution from the initial state, the state of intended purpose, and unknown obstacles. Because of that, the low value of the complex problem-solving gives a concern that students are considered less able to solve complex problems by identifying complex problems, understanding and reviewing related information, and then creating solutions to those problems.

However, the students' skills are highest in the ability to cooperate. To achieve this, partnerships in collaboration then work between services and organizations are needed, and funding and support are very important for organizations to develop the right infrastructure. Information governance arrangements are needed to facilitate information exchange. The potentials to expand the role of voluntary organizations and implications for practitioners regarding job prospects can be explored. That is, high scores on students are the beginning of organizational development in the working world. The high level of skill in collaborating helps in information management that supports organizational services to the right development of infrastructure.

However, viewed from the results of research, it shows that the mastery of students' skills is not yet maximized in which the average is still at 52 percent. These results are still below the ideal level to be said to be worthy of competing in the working world. This shows that even though the co-creation aspect has been done, the results of its implementation still have a gap. This gap is a clear sign that students do not get the education they need in industry 4.0 era and the country does not have enough capable and competent employees (World Economic Forum, 2015). Based on industrial research in Indonesia, it is known only information that seeks soft skills positively enhancing the technical innovation and only positive hard skills influencing the non-technical innovation (Fajar\&Hidajat, 2012). The mastery of these skills is the key to industrial resilience so that it becomes a priority for educational institutions and the industrial world (Mahasneh, Jaser, \&W. Thabet, 2015). Therefore, to narrow the gap, the learning can be improved through the application of the Closed-Loop Instructional System which is integrated with the usage of technology. Research recommendation by Kastolani (2019) states that Islamic education needs digital reorientation to carry out its roles and functions in education. The system has been implemented effectively in various developed countries as reported by The Boston Consulting Group (2011) and the World Economic Forum (2015).

\section{The Closed-Loop Instructional System}

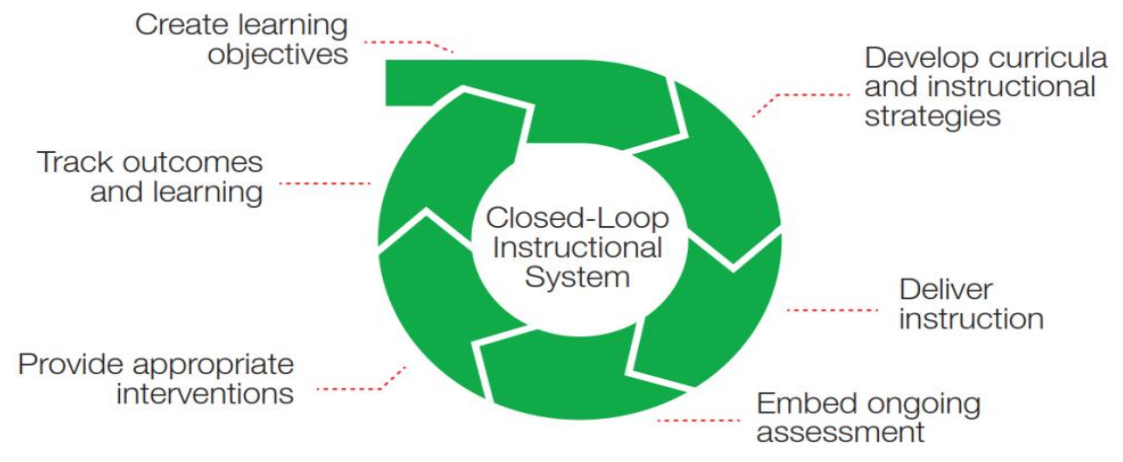

Figure 2: An instructional system known as the closed-loop is necessary to address skills gaps

Source: World Economic Forum, 2015 
Closed-Loop Instructional System is a teaching system cycle consisting of six successive steps, including creating learning objectives, developing curriculum and instructional strategies, delivering instruction, embedding ongoing assessment, providing appropriate interventions, and tracking outcomes and learning (World Economic Forum, 2015). The following application of this system in helping to overcome the inequality of students' skills in co-creation in higher education will be reviewed.

The first step that needs to do in implementing the closed-loop instructional system is to set learning objectives to minimize the inequality of the students' 10 skills as the results of co-creation. Therefore, the learning objectives are directed at 10 skills that students must master when graduated. Technology plays a role in displaying specific learning goals when starting to access digital learning applications.

The imbalance in the mastery of students' skills can be caused by learning objectives that have not been well disseminated to academics. The inequality of understanding of the lecturers on the learning objectives of the institution causes the lack of operationalization of learning objectives in curriculum design and learning. This causes less optimal mastery of students' skills in developing countries so that it has an impact on the lack of optimal value co-creation in higher education. The involvement of higher education in the Industry 4.0 syllabus is an active contribution focused on the needs of users through the provision of trained graduates (Baygin, Yetis, Karakose, \& Akin, 2016).

The second stage is to develop curriculum and learning strategies based on previously defined learning goals. Technology at this stage plays a role in providing abundant teaching resources and materials available online. Lecturers can access by considering the validity according to the needs of students. Therefore, lecturers need to be equipped with special skills in the form of intensive training.

Based on research data, most respondents agreed that the IAIN Salatiga curriculum supports 10 skills needed in the workforce. However, if seen the average mastery is still quite low, the curriculum and learning strategies have not been designed massively so that they have not provided a fundamental improvement effect. This means that curriculum development and learning strategies are important points to solve so that co-creation in higher education can run well.

The delivery of learning should be supported virtually with the blended learning method. This virtual submission helps students get more learning experiences than face-to-face ones in class. Technology helps students explore learning without limits of space and time. Virtual laboratories help students experiment without having to provide expensive equipment and still gain learning experiences without having to make direct contact with hazardous materials. The quality of experiences gained by students through virtual laboratories is not too much different compared to real laboratories. Learning can also be delivered through project-based learning so that it will further hone the students' 10 skills. To provide easy and effective learning materials, lecturers can utilize various computer software such as Microsoft Excel, PowerPoint, Macromedia Flash, etc. (Susilayati, 2019; Susilayati, Toifur, \&Sulisworo, 2017). Tri Dharma Implementation of Indonesian Higher Education is in the form of integration between education and teaching in research \& development, and community services will support this program to run well (Fauziyati, 2017; $\underline{\text { Susilayati, }}$ Mufiq, \&Syamsiyah, 2019).

Submission of learning at IAIN Salatiga that has not been supported virtually further enlarges the gap. The lecture method still has a substantial portion of 44 percent. To minimize the gap, virtual learning needs to be supported immediately. The lecturers need to get technical guidance and special training as well.

At the next stage, an effective ongoing assessment can be adapted from the experience of Summit Public Schools (World Economic Forum, 2015). The Summit provides online curriculum content in the 'digital playlists' design. The playlists contain training contents, videos, and quizzes that are mapped specifically for each skill with the rubric. Students can assess them if they feel ready.

The gaps in the mastery of students' skills can also be caused by the ongoing assessment that has not been entrenched. At present, the assessment is most commonly carried out during the middle of the semester and at the end of the semester. This causes inequality that cannot be detected earlier. Therefore, the ongoing assessment needs to be realized so that inequality can be detected earlier and learning becomes more optimum.

The implementation of the next stage can utilize the results of the assessment in the previous stage. Through the same playlists, students can take remedies if they have not finished or they can continue to the next material if they have been declared complete. The simplest criteria are 'Four criteria', i.e. students are declared complete if they have reached the criteria above 75 percent.

The inequality that occurs at this time can be due to the lack of individual intervention. Learning is carried out classically with 14 face-to-face sessions in each semester. IAIN Salatiga needs to immediately develop a similar 'playlist' so that the gap can be immediately minimized.

In this last stage, the Summit Public School experience can be used as an inspiration. The Summit has used the personalized learning plan (PLP) software. Through PLP, students can evaluate their learning and help plan the achievement of learning goals every week/month/semester/year with the help of a mentor (World Economic Forum, 
2015). The development of students' skills recorded on PLP can be seen by lecturers, staff, students, and parents. Thus, an appropriate intervention can be given to improve the achievement of the skills of each student. This is following the value of co-creation in the interaction of co-production and personalization of value in use.

IAIN Salatiga does not have PLP software. Outcome and learning tracks are only performed at the end of the semester which can be seen by lecturers, students, staff, and parents through 'Sistem Informasi Akademik' called SIAKAD. However, the results that can be seen are only the final values in numbers and letters. The development of the achievement of skills cannot be presented. IAIN Salatiga can adopt tracking outcomes and learning that has been successfully implemented in developed countries so that the gap in co-creation can be minimized.

The successful implementation of the closed-loop instructional system needs support from various parties. Policymakers, educators, education technology providers, funds, and alliances need to carry out their respective roles. Through the role of stakeholders in the form of concrete actions, the quality of learning will increase in line with the effectiveness of the implementation of co-creation in higher education. Furthermore, other aspects of marketing mix such as currency, communal activation, and conversations need developing. So, the next steps of $4 \mathrm{C}$ can be continued to the digital integrated marketing communication 4.0 below.

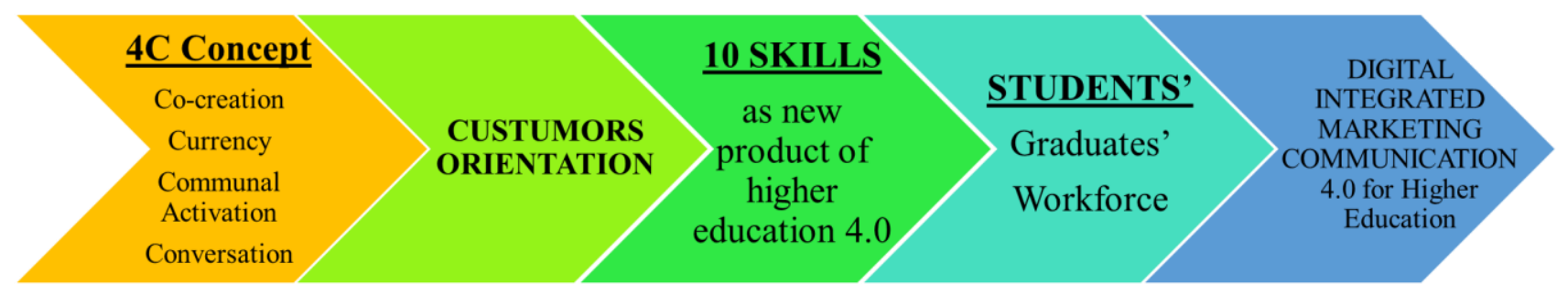

Figure 3: Concept of Digital Integrated Marketing Communication 4.0

Source: Authors' document

Based on Figure 3 above, it shows the emergence of different markets, different needs, different products, and different solutions for industry 4.0 (Damian Ryan \& Calvin Jones, 2012). That is, digital marketing is used as a foundation for marketing strategies. Among other things are what competitors do online, why and how students integrate digital technology into higher education, and how higher education utilizes new and interesting digital channels to foster longer and more productive relationships with students (Damian Ryan \& Calvin Jones, 2012).

Digital Integrated Marketing Communication 4.0 is the application of digital technology to the market through online channels (web, e-mail, databases, plus mobile/wireless and digital TV as well as innovations including blogs, feeds, podcasts, and social networks) to contribute to marketing activities aimed at achieving profitable customer acquisition and retention through digital technology and developing a planned approach to increase audience knowledge (about profiles, behaviors, values, and drivers of loyalty), and then providing integrated targeted communication and online services (Smith \& Chaffey, 2008).

Technological advances are important for the world of education to respond to. In the field of marketing, the concept of digital marketing should have been adopted by the world of education to the level of implementation of the curriculum (Langan, Cowley \& Nguyen, 2019). Today, businesses demand integration. Technology is a power that is usually created outside the marketing domain as a tool that marketers have to control the new world through co-creation (Crittenden \& Crittenden, 2015). Digitally integrated marketing communication 4.0 for Higher Education that is implemented optimally can support "The Great Reset" as Covid-19 pandemicresponses.

\section{CONCLUSION}

Co-creation in higher education consists of co-production and value-in-use obtained from the learning process. Quality learning produces quality students as a product and customer in co-creation. The results of the study propose students' mastery of 10 skills as a new product of co-creation in higher education. Students' mastery of 10 skills at IAIN Salatiga is fair and quite ready to continue to the next steps of digital integrated marketing and communication 4.0. The inequality of skills (skills gap) can be minimized through the use of technology that is integrated with the teaching system. The study recommends the use of the closed-loop instructional system in higher education so that the implementation of co-creation runs optimally. Furthermore, other aspects of marketing mix such as currency, communal activation, and conversations need developing so that digitally integrated marketing communication 4.0 can have a positive effect on higher education to survive and support "The Great Reset".

\section{LIMITATION AND STUDY FORWARD}

This study only implements co-creation as the first step of the $4 \mathrm{C}$ concept. Further studies can implement other aspects of marketing mix such as currency, communal activation, and conversations so that the $4 \mathrm{C}$ concept can run optimally. After that, digitally integrated marketing communication 4.0 can be run effectively too. 
Implications - The findings of this study can be made as study materials for university managers so that they can concoct appropriate integrated marketing and communication in the 4.0 era.

Co-Author contribution - The first author presented the idea, designed, and directed the project with other authors. For conceiving the presented idea, all co-authors developed the digitally integrated marketing theory. The second and fourth authors developed the methodology and performed the computations. The first author verified the analytical methods. The second, third, and fourth authors collected the data, and then all authors discussed the results and contributed to the final manuscript. In their discussion, the first author focused on digital reorientation in higher education. The second author focused on digitally integrated marketing communication 4.0. The third author focused on 4P's theory. And the Fourth author focused on education and teaching effectiveness in higher education. Then, the first and third authors developed the co-creation in the higher-education framework. The first and second authors developed digitally integrated marketing communication 4.0; the first and fourth authors simulated the data with the closed-loop instructional systems. All co-authors contributed to writing the article following their scientific backgrounds.

\section{ACKNOWLEDGMENT}

The authors wish to thank all respondents that are willing to fill the questionnaire with sincerity and honesty.

\section{REFERENCES}

1. Arenggoasih, W. (2019). Social media as moderation in the middle of plurality in the industri 4.0. In Proceeding of International Conference on Social and Political Science (pp. 224-234).

2. Baygin, M., Yetis, H., Karakose, M., \& Akin, E. (2016). An effectanalysis of industry 4.0 to higher education. In 15th International Conference on Information Technology based Higher Education and Training (ITHET). Istambul: IEEE.https://doi.org/10.1109/ITHET.2016.7760744

3. Bovill, C., Cook-Sather., Felten, P., Millard, L., \& Moore-Cherry, N. (2016). Addressing potential challenges in co-creating learning and teaching: Overcoming resistance, navigating institutional norms and ensuring inclusivity in student-staff partnership. Higher Education, 71 (2), 195-208.https://doi.org/10.1007/s10734-0159896-4

4. Bowden, J. L. H. (2011). Engaging the students as a customer:A relationship marketing approach. Marketing Education Review, 21(3), 211-288.https://doi.org/10.2753/MER1052-8008210302

5. Bowden, J. L. H., \& D'Alessandro, S. (2011). Co-creating value in higher education: The role of interactive classroom response technologies. Asian Social Science, 7(11), 35. https://doi.org/10.5539/ass.v7n11p35

6. Cook-Sather, A., Bovill, C., \&Felten, P. (2014). Engaging students as partners in learning and teaching: A guide for faculty. Hoboken: John Wiley \& Sons.

7. Crittenden, Victoria and William Crittenden. (2015). Digital and social media marketing in business education: Implications for the marketing curriculum. Journal of Marketing Education, 37(2), 7175.https://doi.org/10.1177/0273475315588111

8. D'Alessio, F. A., Avolio, B. E., \& Charles, V. (2019). Studying the impact of critical thinking on the academic performance of executive MBA students. Thinking Skills and Creativity, 31, 275-283. https://doi.org/10.1016/j.tsc.2019.02.002

9. Damian Ryan, \& Calvin Jones. (2012). Understanding digital marketing: Marketing strategies for engaging the digital generation. London: Kogan Page Publishers.

10. Dodgson, M., \& Gann, D. (2020). Great Reset: What university entrepreneurship can bring to the post-COVID world. Retrieved from https://www.weforum.org/agenda/2020/07/university-entrepreneurship-post-covid-19world/

11. Dollinger, Mollie, Jason Lodge \& Hamish Coates. (2018). Co-creation in higher education: Towards a conceptualmodel. Journal of Marketing for Higher Education, 28 (2), 122.https://doi.org/10.1080/08841241.2018.1466756

12. Elsharnouby, T. H. (2015). Studenet co-creation beharior in higher education: The role of satisfaction with the university experience. Journal of Marketing for Higher Education, 25 (2), 238262.https://doi.org/10.1080/08841241.2015.1059919

13. Estawara. (2008). Think IMC!. Jakarta: GramediaPustaka Utama.

14. Fajar, A., \&Hidajat, J. (2012). Relationship among soft skills, hardskills and innovativeness of knowledge workers in the knowledge. Procedia - Social and Behavioral Sciences, 52, 35-44. https://doi.org/10.1016/j.sbspro.2012.09.439

15. Fauziyati, D. (2017). Integration of Islamic education renewal with science and technology in realizing tridharmaperguruantinggi (three principles of higher education). Karunia, 13(2), 31-34.

16. Fill, Christ. (1999). Marketing communications contex, contents and strategies, 2nd edt. New Jersey: Prentice Hall.

17. Funke, J. \&Frensch, (1995). Complex problem solving research in north America and Europe: An Integrative Review. 62 https://www.psychologie.uni-heidelberg.de.

18. Gau, W. B. (2019). A reflection on marketing 4.0 from the perspective of seniorcitizens' communities of practice. SAGE Open, 9(3), 2158244019867859.https://doi.org/10.1177/2158244019867859 
19. Ginting, G. (2014). The power of consumer community: Open innovation melalui co-creation value sebagailangkahstrategismempertahankan survival bisnis (pp. 45-54). Conference on Management and Behavioral Studies (CMBS).

20. Gray, A. (2016). The 10 skills you need to thrive in the fourth industrial revolution. Retrieved April 18, 2019, from World Economic Forum website: https://www.weforum.org/agenda/2016/01/the-10-skills-you-need-tothrive-in-the-fourth-industrial-revolution/.

21. Gunarto, M. (2018). Model co-creation dan implikasinyaterhadaployalitasmahasiswaperguruantinggiswasta (Studi pada PTS di Provinsi Sumatera Selatan). Universitas Pendidikan Indonesia.

22. Hendriyana, A. (2019). Kemampuanberpikirkritistidakakantergantikan di era revolusiindustri 4.0. Retrieved April 18, 2019, from UniversitasPadjadjaran website: http://www.unpad.ac.id/2019/03/kemampuan-berpikirkritis-tidak-akan-tergantikan-di-era-revolusi-industri-4-0/

23. Judson, K. M., \& Taylor, S. A. (2014). Moving form marketization to marketing of higher education: The cocreation of value in higher education. Higher Education Studies, 4(1), 51. https://doi.org/10.5539/hes.v4n1p51

24. Juska, Jerome M. (2017). Integrated marketing communication: Advertising and promotion in a digital world. London: Routledge.https://doi.org/10.4324/9781315526812

25. Kartajaya, Hermawan (2007). Hermawankartajaya on marketing mix. Bandung: MizanPustaka.

26. Kastolani. (2019). Digital reorientation of Islamic higher education in Indonesia. Akademika, 24(1), $151-164$.

27. Kotler, Philip., HermawanKartajaya\&IwanSetiawan. (2019). Marketing 4.0: Bergerakdaritradisionalke digital. Jakarta: GramediaPustaka Utama.

28. Krauss, M. (2017). Marketing 4.0 Argues the market placehas changed, and the customer is in control. Marketing News, 51(4), 26-27.

29. Kriyantono, R. (2014). Teknik praktisrisetkomunikasi. Jakarta: KencanaPrenada Media.

30. Laar, E. Van., Deursen, A. J. A. M. Van., Dijk, Jan. A. G. M. Van., \&Haan, D. J. (2019). The sequential and conditional nature of 21st-century digital skills. International Journal of Communication, 13(409), 3462-3487.

31. Langan, Ryan., Scott Cowley., Carlin Nguyen. (2019). The State of digital marketing in academia: an examination of marketing curriculum's response to digital disruption. Journal of Marketing Education, 41(1), 32-46.https://doi.org/10.1177/0273475318823849

32. Lusch, R. F., \& Vargo, S. L. (2006). Service-dominant logic: Reactions, reflections and refinements. Marketing Theory, 6(3), 281-288.https://doi.org/10.1177/1470593106066781

33. Mahasneh, J., \&Thabet, W. (2015). Rethinking construction curriculum: A descriptive cause analysis for soft skills gap among construction graduates. In 51st ASC Annual International Conference Proceedings. Associated Schools of Construction.

34. Mclellan, Sarah. (2018). University 4.0: Is the UK doing enough to prepare students for the fourth industrial revolution? Retrieval from http://blogs.brighton.ac.uk/thedigitalrevolution/2018/04/03/uk-preparing-studentsfourth-industrial-revolution/

35. Muller, E., \& Peres, R. (2019). The effect of social networks structure on innovation performance: A review and directions for research. International Journal of Research in Marketing, 36(1), 3-19. https://doi.org/10.1016/j.ijresmar.2018.05.003

36. Prahalad, C. K., \& Ramaswamy, V. (2003). The New new frontier of experience innovation. MIT Sloan Management Review, 44(4), 12-18.

37. Prahalad, C. K., \& Ramaswamy, V. (2004). Co-creation experiences: The next practice in value creation. Journal of Interactive Marketing, 18(3), 5-14.https://doi.org/10.1002/dir.20015

38. Puspitarini, M. (2014). Empat factor penunjangkeberhasilan Pendidikan tinggi: Okezone News. Retrieved April 22, 2019, from https://news.okezone.com/read/2014/09/23/373/1043157/empat-faktor-penunjangkeberhasilan-pendidikan-tinggi

39. Ramirez, R. (1999). Value co-production: Intellectual origins and implications for practice and research. Strategic Management Journal, 20, 49-65.https://doi.org/10.1002/(SICI)1097-0266(199901)20:1<49::AIDSMJ20>3.0.CO;2-2

40. Ranjan, K. R., \& Read, S. (2016). Value co-creation: Concept and measurement. Journal of the Academy of Marketing Science, 44(3), 290-315.https://doi.org/10.1007/s11747-014-0397-2

41. Rediekan, G., \&Respati, W. S. (2013). Sikaporangtuaterhadapperilakuseksualpranikahdikomplek XXX Tangerang. 11, 13.

42. Robles, M. M. (2012). Executive perceptions of the top 10 soft skills needed in today's workplace. Bisnis Communication Quarterly, 75(4), 453-465. https://doi.org/10.1177/1080569912460400

43. Schultz, Don E and Heidi Schultz. (2003). IMC, the next generation: Five steps for delivering value and measuring returns using marketing communication. Pennsylvania: McGraw Hill Professional.

44. Sihite, M. (2016). Marketing perguruantinggi. MajalahIlmiahMethoda, 6(2), 64-78.

45. Smith, P. R., \& Chaffey, D. (2008). eMarketing eXcellence. London: Routledge.https://doi.org/10.4324/9780080878966 
46. Susilayati, M. (2019). Pengembangan model pembelajaran IPA terintegrasimenggunakan Ms. Excel bagimahasiswa PGSD/ PGMI. Al Ghazali, Jurnal Kajian Pendidikan Islam dan Studi Islam, 2(1), 19.https://ejournal.stainupwr.ac.id/index.php/al_ghzali/article/view/105

47. Susilayati, $\quad$ M., $\quad$ Mufiq, $\quad$ M., $\quad$ Syamsiyah, $\quad$ B. $\quad$ (2019). Paradigmafisikaqur'anidalamtridharmaperguruantinggikeagamaan Islam. Al-A'raf, JurnalPemikiran Islam dan Filsafat, 16(2), 161-186. https://doi.org/10.22515/ajpif.v16i2.1696

48. Susilayati, M., Toifur, M., \&Sulisworo, D. (2017). Optimalisasipembelajaran IPA/Fisikaterintegrasidenganvisualisasiisyaratilmiah Qs. al-A'rafayat 54. Attarbiyah, 27(December), 78. ttps://doi.org/10.18326/tarbiyah.v27i0.78-94

49. Tarabasz, A. (2013). The Reevaluation of communication in customer approach-towards marketing 4.0. International Journal of Contemporary Management, 12, 124-134.

50. The Boston Consulting Group. (2011). Unleasing the potential of technology in education. Boston: The Boston Consulting Group, Inc.

51. Wei, Y., \& Huang, P. (2019). A model of product compatibility introduction with consumer recognition. International Journal of Research in Marketing, 36(4), 613-629. https://doi.org/10.1016/j.ijresmar.2019.03.001

52. Widoyoko, EkoPutro S. (2009). Evaluasi program pembelajaran. Yogyakarta: Putra Pelajar.

53. World Economic Forum. (2015). New vision for education unlocking the potential of technology. Cologny: World Economic Forum $\circledR$.

54. 50minutes.com. (2015). The marketing mix: Master the 4Ps of marketing. Cork: Primento digital. 